\title{
DA EXTINÇÃO DO MANDAdO DE SEGURANÇA PELA AUSÊNCIA DO INTERESSE DE AGIR CONTRA ATO ADMINISTRATIVO EM LICITAÇÃO PÚBLICA $^{1}$
}

\section{THE ABATEMENT OF ACTION DUE TO THE LACK OF INTEREST TO SUE IN \\ THE WRIT OF MANDAMUS AGAINST AN ADMINISTRATIVE ACT IN A PUBLIC BIDDING}

Flavio Augusto de Castro Barboza Advogado concursado da Companhia de Geração Térmica de Energia Elétrica (Eletrobras CGTEE) localizada em Porto Alegre/RS. Bacharel em Ciências Jurídicas e Sociais pela Faculdade de Direito da Pontifícia Universidade Católica do Rio Grande do Sul. Especialista em Direito Empresarial pela Faculdade de Direito da Pontifícia Universidade Católica do Rio Grande do Sul. Especialista em Direito Processual Civil pela UNICID UNIVERSIDADE CIDADE DE SÃO PAULO. flabirdman2@gmail.com

RESUMO: O objetivo do artigo é analisar a extinção do processo sem resolução do mérito pela ausência do interesse de agir no mandado de segurança impetrado contra ato em licitação pública, quando não é concedida liminar e o certame tem prosseguimento. O mandado de segurança impetrado contra atos em licitações deve atender os requisitos das condições da ação previstos no Código de Processo Civil, dentre os quais o interesse de agir, sob pena de perda de objeto e extinção do processo sem resolução do mérito nos termos da Lei $n^{\circ}$. 12.016/2009. Segundo a doutrina, indeferida a liminar do certame e tendo sido homologado o objeto com a celebração do contrato, há ausência de interesse de agir. Todavia, a jurisprudência atual do Superior Tribunal de Justiça passou a decidir que a nulidade do ato contamina todas as fases do certame, inclusive o contrato, impedindo a extinção do processo, isto é, não há perda de objeto. No Tribunal Regional

\footnotetext{
${ }^{1}$ Artigo recebido em 20/01/2015 e aprovado em 10/05/2015.
} 
Revista Eletrônica de Direito Processual - REDP. Volume 15. Janeiro a Junho de 2015 Periódico Semestral da Pós-Graduação Stricto Sensu em Direito Processual da UERJ. Patrono: José Carlos Barbosa Moreira. www.redp.com.br ISSN 1982-7636 PP 213-239 Federal da $4^{\mathrm{a}}$ Região e no Tribunal de Justiça do Estado do Rio Grande do Sul, não há uma aplicação harmônica sobre esse entendimento. Assim, enquanto persistir a jurisprudência atual, a Administração deverá aprimorar a fundamentação de seus atos, a fim de reduzir o risco de questionamento judicial de suas decisões.

PALAVRAS-CHAVE: Mandado de segurança. Liminar. Extinção. Resolução. Mérito. Condições da ação. Interesse de agir. Licitação. Adjudicação. Homologação. Contrato. Administração Pública.

ABSTRACT: The purpose of this article is to examine the abatement of action due to the lack of interest to sue in the writ of security against an act in a public bidding, when an injunction is not granted and the bidding proceeds. The writ of security against acts in biddings must comply with the action conditions established in the Civil Procedure Code, among which the interest to sue, under penalty of loss of object and abatement of action according to the Federal Law 12.016/2009. According to the doctrine, rejected the injunction, and once the bidding process is homologated with the agreement signing, there is no interest to sue. However, the current case law of the Supreme Court went on to decide that the nullity of the act contaminates all stages of the proceeding, including the contract, preventing the extinction of the proceedings, that is, there is no loss of object. The Federal Court of the 4th Region and the Court of Justice of the Rio Grande do Sul State, there is a harmonious application of this understanding. So while persist the current case law, the Administration should enhance the reasons for their actions in order to reduce the risk of legal challenge of their decisions.

KEYWORDS: Writ of Security. Injunction. Abatement. Termination. Ground of Action. Action Conditions. Interest to Sue. Bidding. Adjudication. Homologation. Contract. Public Administration.

\section{Introdução}

O mandado de segurança é uma ação constitucional que pode ser impetrada contra atos da Administração Pública em licitações que violem direito líquido e certo do 
Revista Eletrônica de Direito Processual - REDP. Volume 15. Janeiro a Junho de 2015 Periódico Semestral da Pós-Graduação Stricto Sensu em Direito Processual da UERJ. Patrono: José Carlos Barbosa Moreira. www.redp.com.br ISSN 1982-7636 PP 213-239

impetrante, uma vez que o procedimento licitatório deve obedecer à legislação vigente, especificamente a Lei $n^{0}$. 8.666/1993, sob pena de nulidade. Assim, a Administração Pública, na execução de suas atividades para o atendimento do interesse público, deverá levar em consideração para a conclusão eficaz de suas licitações esse risco judicial decorrente da possibilidade de anulação de todo o procedimento, desde o Edital até sua conclusão.

Por sua vez, a petição do impetrante do remédio constitucional deverá atender os requisitos das condições da ação previstos no Código de Processo Civil, dentre os quais o interesse de agir, sob pena de perda de objeto e extinção do processo sem resolução do mérito nos termos da Lei $\mathrm{n}^{0} .12 .016 / 2009$.

Todavia, não sendo deferida liminar no mandado de segurança para suspender a licitação, não se pode presumir que a autoridade administrativa permaneça inerte, sem dar prosseguimento ao certame licitatório. Pelo contrário, até em consonância com o princípio da continuidade do serviço público, deve o administrador prosseguir exercendo sua função, adjudicando, homologando e celebrando o contrato. É inviável, nesta altura, retornar-se ao status quo ante. Nesse cenário, analisa-se o interesse de agir do impetrante sob o aspecto da necessidade e da utilidade da ação constitucional. Logo, o problema do presente artigo é o seguinte: Haverá extinção do processo sem resolução do mérito pela ausência do interesse de agir no mandado de segurança impetrado contra ato em licitação pública, quando não é concedida liminar e o certame tem prosseguimento?

A legislação do mandado de segurança admite a sua denegação e, consequentemente, a extinção do processo sem resolução do mérito, quando ausente o interesse de agir previsto no Artigo 267 do Código de Processo Civil. Em tendo sido ultimado o certame licitatório, sem sua paralisação liminar, com a execução do contrato haverá a extinção do mandado de segurança por falta de interesse processual superveniente.

A doutrina corrobora esse entendimento, inclusive entre os autores consagrados no exame da matéria, tais como Humberto Theodoro Junior ${ }^{2}$, Hely Lopes Meirelles ${ }^{3}$,

\footnotetext{
2 THEODORO JUNIOR, Humberto. O Mandado de Segurança Segundo a Lei n ${ }^{\circ} .12 .016$, de 07 de agosto de 2009. Rio de Janeiro: Forense, 2009.2009, p.34.

${ }^{3}$ MEIRELLES, Hely Lopes; WALD, Arnoldo; MENDES, Gilmar Ferreira. Mandado de Segurança e Ações Constitucionais. 32. ed. São Paulo: Editora Malheiros, 2009, p.105.
} 
Revista Eletrônica de Direito Processual - REDP. Volume 15. Janeiro a Junho de 2015 Periódico Semestral da Pós-Graduação Stricto Sensu em Direito Processual da UERJ. Patrono: José Carlos Barbosa Moreira. www.redp.com.br ISSN 1982-7636 PP 213-239

entre outros. Assim, ausente a condição da ação, o mandado não preenche os requisitos do Código de Processo Civil.

Se, de um lado, a Constituição Federal protege o direito líquido e certo do impetrante, de outro, assegura a supremacia do interesse público. Quando o impetrante não utilizar o mandado de segurança adequadamente, não é razoável que a Administração interrompa uma licitação. Assim, ainda que extinto o processo, consagraram-se alternativas legais para o impetrante, de modo que a garantia de acesso ao Judiciário e o controle dos atos administrativos não sejam prejudicados. O que não se admite é a continuidade da ação constitucional sem o interesse processual útil à solução da demanda.

Apesar da previsão legal, a jurisprudência atual do Superior Tribunal de Justiça (STJ) rompeu esse paradigma, com reflexos no Tribunal Regional Federal da $4^{\mathrm{a}}$ Região e no Tribunal de Justiça do Estado do Rio Grande do Sul. Até alguns anos atrás, predominava nos Tribunais do país o entendimento de que a ausência do interesse de agir levava à extinção da ação mandamental. A partir de 2009, o Superior Tribunal de Justiça mudou seu entendimento, passando a decidir que a nulidade contamina todas as fases do certame, inclusive o contrato, impedindo a extinção do processo, isto é, não há perda de objeto.

O Tribunal Regional Federal da $4^{\circ}$ Região adotou esse posicionamento. Por sua vez, no Tribunal de Justiça do Estado do Rio Grande do Sul, as Câmaras Cíveis da Corte apresentam entendimentos divergentes.

Sob a ótica da Administração Pública, o novo entendimento do Superior Tribunal de Justiça aumenta o risco judicial dos atos administrativos em licitações públicas. Não havendo a suspensão liminar do certame, a adjudicação, a homologação, a celebração e a execução do contrato podem ser anuladas retroativamente. Sendo assim, é relevante a análise do tema, visto que a Administração Pública, com a missão de atender a sua finalidade, não pode ficar a mercê dessa insegurança jurídica. Para que haja a correta avaliação da legalidade do ato, devem ser levados em consideração dois planos distintos, o do direito material e o do direito processual, sendo necessário encontrar uma medida que atenda ambos cenários.

Portanto, o objetivo geral é encontrar uma solução para o problema apresentado, buscando-se uma resposta adequada diante da indefinição jurisprudencial, 
Revista Eletrônica de Direito Processual - REDP. Volume 15. Janeiro a Junho de 2015

Periódico Semestral da Pós-Graduação Stricto Sensu em Direito Processual da UERJ.

Patrono: José Carlos Barbosa Moreira. www.redp.com.br ISSN 1982-7636 PP 213-239

a fim de guiar a condução de uma licitação judicializada, reduzindo-se o risco de judicial de sua anulação.

\section{Da Legislação e da Doutrina}

O mandado de segurança, previsto na Constituição Federal $^{4}$, pode ser impetrado contra atos da Administração Pública em licitações para a aquisição de produtos ou para a contratação de prestação de serviços que violem direito líquido e certo do impetrante. Para tanto, a petição deverá preencher os requisitos processuais exigidos na legislação específica.

Os atos na licitação são passíveis de exame judicial, pois o procedimento licitatório deverá obedecer à legislação vigente sob pena de nulidade. Afinal, a Constituição Federal estabelece que a Administração Pública se submete ao princípio da legalidade no Artigo 37, caput $^{5}$ e, no Inciso XXI do referido Artigo, que as obras, serviços, compras e alienações serão contratadas mediante processo de licitação pública nos termos da lei. ${ }^{6}$

Consoante o Parágrafo $2^{\circ}$ do Artigo $49^{\circ}$ da Lei $n^{\circ} .8 .666 / 93^{7}$, que regulamenta o referido dispositivo constitucional e estabelece normas para licitações e contratos da Administração Pública, o ato executado em desacordo com a Lei, como regra geral é nulo, sendo que a nulidade da licitação induz a do contrato. Assim, os atos realizados em uma licitação são suscetíveis de apreciação pelo Poder Judiciário, seja através de ação ordinária, seja através de mandado de segurança.

De acordo com a doutrina:

\footnotetext{
${ }^{4}$ BRASIL. Assembleia Nacional Constituinte. Constituição da República Federativa do Brasil de 1988, Artigo 5º Inciso LXIX. Diário Oficial da União, Brasília, DF, 5.10.1988. Disponível em: $<$ http://www.planalto.gov.br/ccivil_03/constituicao/constituicao.htm>. Acesso em: 18 ago 2014.

${ }^{5}$ BRASIL. Assembleia Nacional Constituinte. Constituição da República Federativa do Brasil de 1988, Artigo 37. Diário Oficial da União, Brasília, DF, 5.10.1988. Disponível em: $<$ http://www.planalto.gov.br/ccivil_03/constituicao/constituicao.htm>. Acesso em: 18 ago 2014.

${ }^{6}$ BRASIL. Assembleia Nacional Constituinte. Constituição da República Federativa do Brasil de 1988, Artigo 37, Inciso XXI. Diário Oficial da União, Brasília, DF, 5.10.1988. Disponível em: $<$ http://www.planalto.gov.br/ccivil_03/constituicao/constituicao.htm>. Acesso em: 18 ago 2014.

${ }^{7}$ BRASIL. Congresso Nacional. Lèi no 8.666, de 21 de junho de 1993. Regulamenta o art. 37, inciso XXI, da Constituição Federal, institui normas para licitações e contratos da Administração Pública e dá outras providências: Artigo 49, Parágrafo $2^{\circ}$. Diário Oficial da União, Brasília, DF, 22.6.1993. Disponível em: < http://www.planalto.gov.br/ccivil_03/leis/18666cons.htm >. Acesso em: 18 ago 2014.
} 
Revista Eletrônica de Direito Processual - REDP. Volume 15. Janeiro a Junho de 2015

Periódico Semestral da Pós-Graduação Stricto Sensu em Direito Processual da UERJ.

Patrono: José Carlos Barbosa Moreira. www.redp.com.br ISSN 1982-7636 PP 213-239

É amplo o horizonte das possíveis ações judiciais em matéria de licitação. Todo e qualquer ato, comportamento, procedimento, decisão, procedido em certame licitatório, está sujeito a apreciação judicial. Trata-se da própria impositividade à Administração da garantia ao cidadão (ao licitante, portanto) pelo inc. $X X X V$ do art. $5^{\circ}$ da Constituição: 'a lei não excluirá da apreciação do Poder Judiciário lesão ou ameaça a direito ‘ ${ }^{8}$

Denota-se que a Administração Pública na execução de suas atividades para o atendimento do interesse público deverá levar em consideração o risco judicial para a conclusão eficaz de suas licitações.

Por sua vez, o mandado de segurança submete-se à legislação processual própria. A petição do impetrante do mandamus deverá atender os requisitos das condições da ação, dentre os quais o interesse de agir, previsto no Artigo $3^{\circ}$ do Código de Processo Civil, ${ }^{9}$ sob pena de perda de objeto e extinção do processo sem resolução do mérito. Essa regra estava disposta na revogada Lei $n^{\circ} .1 .533 / 1951^{10}$ e está prevista no Artigo $6^{\circ}$ da Lei Federal vigente $\mathrm{n}^{\mathrm{o}} .12 .016 / 2009 .{ }^{11} \mathrm{O}$ referido artigo estipula a extinção do mandado nos casos previstos no Artigo 267 do Código de Processo Civil.

Segundo os autores processualistas, o interesse de agir é um binômio, ou seja, o instrumento jurisdicional deve ser útil e necessário:

\footnotetext{
${ }^{8}$ RIGOLIN, Ivan Barbosa; BOTTINO, Marco Tullio. Manual Prático de Licitações. 5. ed. São Paulo: Saraiva, 2005, p.440-441.

${ }^{9}$ BRASIL. Congresso Nacional. Lei ${ }^{\circ}$ 5.869, de 11 de janeiro de 1973. Institui o Código de Processo Civil. Artigo $3^{\circ}$. Diário Oficial da União, Brasília, DF, 17.1.1973. Disponível em: $<$ http://www.planalto.gov.br/ccivil_03/Leis/L5869.htm>. Acesso em: 18 ago 2014.

${ }^{10}$ BRASIL. Congresso Nacional. Lei n ${ }^{\circ} .1 .533$, de 31 de dezembro de 1951. Altera disposições do Código do Processo Civil, relativas ao mandado de segurança. Art. $6^{\circ}$ - A petição inicial, que deverá preencher os requisitos dos artigos 158 e 159 do Código do Processo Civil, será apresentada em duas vias e os documentos, que instruírem a primeira, deverão ser reproduzidos, por cópia, na segunda. Diário Oficial da União, Brasília, DF, 31.12.1951. Disponível em: <http://www.planalto.gov.br/ccivil_03/leis/11533.htm>. Acesso em: 18 ago 2014.

${ }^{11}$ BRASIL. Congresso Nacional. Lei $\mathrm{n}^{0}$ 12.016, de 07 de agosto 2009. Disciplina o mandado de segurança individual e coletivo e dá outras providências. Artigo $6^{\circ}$. Diário Oficial da União, Brasília, DF, 10.8.2009. Disponível em: < http://www.planalto.gov.br/ccivil_03/_ato2007-2010/2009/lei/112016.htm>. Acesso em: 18 ago 2014.
} 
Revista Eletrônica de Direito Processual - REDP. Volume 15. Janeiro a Junho de 2015 Periódico Semestral da Pós-Graduação Stricto Sensu em Direito Processual da UERJ. Patrono: José Carlos Barbosa Moreira. www.redp.com.br ISSN 1982-7636 PP 213-239

$O$ interesse de agir é representado pela relação entre a situação antijurídica denunciada e o provimento que se pede para debelá-la mediante a aplicação do direito; deve essa relação consistir na utilidade do provimento, como meio para proporcionar ao interesse lesado a proteção concedida pelo direito. $^{12}$

Consoante os doutrinadores, a atividade jurisdicional deve extrair um resultado útil, ou seja, "o provimento deve corrigir o mal de que o autor se queixa, sob pena de não ter razão de ser". ${ }^{13}$

Portanto, se não houver utilidade do provimento jurisdicional, não há interesse processual:

O interesse processual, a um só tempo, haverá de traduzir-se numa relação de necessidade e também numa relação de adequação do provimento postulado, diante do conflito de direito material trazido à solução judicial. Mesmo que a parte esteja na iminência de sofrer um dano em seu interesse material, não se pode dizer que exista o interesse processual, se aquilo que se reclama do órgão judicial não será útil juridicamente para evitar a temida lesão. ${ }^{14}$

Assim, o interesse processual, enquanto condição da ação exigida no Código de Processo Civil, também deve estar presente no mandado de segurança por imposição da legislação federal específica. De acordo com a doutrina, "no que tange as condições da ação, nada de diferente acontece na ação mandamental que não ocorra nas demais ações". ${ }^{15}$

\footnotetext{
12 MARINONI, Luiz Guilherme. Teoria Geral do Processo. 4. ed. São Paulo: Editora Revista dos Tribunais, 2010, v. 1, p.174.

${ }^{13}$ CINTRA, Antonio Carlos de Araujo; GRINOVER, Ada Pellegrini; DINAMARCO, Candido Rangel. Teoria Geral do Processo. 26. ed. São Paulo: Malheiros, 2010, p.182.

${ }^{14}$ THEODORO JÚNIOR, Humberto. Curso de Direito Processual Civil. Rio de Janeiro: Forense, 1999. v. 1, p.57.

${ }^{15}$ ALVIM, J. E. Carreira. Comentários à Nova Lei do Mandado de Segurança - Lei 12016/09. 1. ed. Curitiba: Juruá, 2009, p.143.
} 
Revista Eletrônica de Direito Processual - REDP. Volume 15. Janeiro a Junho de 2015 Periódico Semestral da Pós-Graduação Stricto Sensu em Direito Processual da UERJ. Patrono: José Carlos Barbosa Moreira. www.redp.com.br ISSN 1982-7636 PP 213-239

$\mathrm{O}$ interesse de agir no mandado de segurança corresponde à tutela apta a proteger o direito: "Por interesse processual (ou interesse de agir) se entende a necessidade da tutela jurisdicional para evitar lesão ou ameaça a direito, ou, em outros termos, a necessidade de se invocar a prestação jurisdicional num caso concreto; "16

Para fins de ilustração, apresenta-se um caso hipotético no qual há ausência do interesse de agir no mandado de segurança, visto que a requerente não obteve êxito no pedido liminar. Sem obstáculos a suspender seu curso natural, concluiu-se o procedimento licitatório, com a adjudicação de seu objeto e o início da execução dos serviços contratados. Poder-se-ia cogitar, até mesmo, a entrega de um bem adquirido, ou a conclusão de uma obra, extinguindo-se o contrato.

Ora, a autoridade administrativa não pode permanecer inerte em consonância com o princípio da continuidade do serviço público. Dando-se prosseguimento ao certame, é inviável, nesta altura, retornar-se à situação anterior, configurando-se a ausência do interesse de agir.

A doutrina expõe que a ação inadequada à solução do litígio leva à ausência do interesse processual:

Também não revela interesse a parte que pede providência jurisdicional inábil à solução do litígio ou à realização do direito, como seria hipótese de se nunciar obra já terminada, orientando-se pelo procedimento da nunciação de obra nova. ${ }^{17}$

Em tendo sido ultimado o certame licitatório, com a execução do contrato, revela-se evidente a ausência de interesse processual, devendo o processo ser extinto sem resolução do mérito nos termos do Inciso VI do Artigo 267 do Código de Processo Civil. ${ }^{18}$ Ausente uma das condições, ocorre o fenômeno da carência de ação previsto no Inciso X do Artigo 301 do Código de Processo civil ${ }^{19}$. A doutrina assim aborda o tema:

\footnotetext{
${ }^{16}$ Idem. Ibidem. p.144.

17 SANTOS, Ernane Fidélis dos. Manual de Direito Processual Civil. São Paulo: Saraiva, 1998. v. 1, p.515.

${ }^{18}$ BRASIL. Congresso Nacional. Lei no 5.869, de 11 de janeiro de 1973. Institui o Código de Processo Civil. Artigo 267, Inciso VI. Diário Oficial da União, Brasília, DF, 17.1.1973. Disponível em: $<$ http://www.planalto.gov.br/ccivil_03/Leis/L5869.htm>. Acesso em: 18 ago 2014.

${ }^{19}$ BRASIL. Congresso Nacional. Lei $\mathrm{n}^{\circ}$ 5.869, de 11 de janeiro de 1973. Institui o Código de Processo Civil. Artigo 301, Inciso X. Diário Oficial da União, Brasília, DF, 17.1.1973. Disponível em: $<$ http://www.planalto.gov.br/ccivil_03/Leis/L5869.htm>. Acesso em: 18 ago 2014.
} 
Revista Eletrônica de Direito Processual - REDP. Volume 15. Janeiro a Junho de 2015

Periódico Semestral da Pós-Graduação Stricto Sensu em Direito Processual da UERJ.

Patrono: José Carlos Barbosa Moreira. www.redp.com.br ISSN 1982-7636 PP 213-239

Ausente uma delas ou mais de uma ocorre o fenômeno da carência de ação (CPC 301 X), circunstância que torna o juiz impedido de examinar o mérito. A carência de ação tem como consequência a extinção do processo sem resolução do mérito (CPC $267 \mathrm{VI}) .^{20}$

Ora, a legislação do mandado de segurança admite a sua denegação e, consequentemente, a extinção do processo sem resolução do mérito, quando ausente o interesse de agir. A doutrina reconhece essa disposição: "Nem sempre a sentença que põe termo a ação de segurança enfrenta o mérito da causa". ${ }^{21}$ Não há dúvida na doutrina quanto à possibilidade da extinção do mandado pela ausência do interesse de agir:

A sentença em mandado de segurança poderá ser de carência ou de mérito, se antes não tiver sido indeferida a petição inicial por não ser caso de impetração, não atender as exigências formais da lei ou quando decorrido o prazo legal para impetração ... A carência ocorre quando o impetrante não satisfaz os pressupostos processuais e as condições do direito de agir, tal como previsto no art.267, VI do CPC. ${ }^{22}$

Por sua vez, em consonância com a garantia constitucional de acesso ao Judiciário, a própria legislação estabelece mecanismos que asseguram ao impetrante outras medidas judiciais. O Parágrafo $6^{\circ}$ do Artigo $6^{\circ}$ da legislação autoriza a renovação do pedido, quando a decisão denegatória não examinar o mérito, sendo que o Artigo 19 da mesma norma dispõe que o requerente poderá ingressar com ação própria. ${ }^{23}$

\footnotetext{
${ }^{20}$ NERY JUNIOR, Nelson; NERY, Rosa Maria de Andrade. Código de Processo Civil Comentado e Legislação Vigente. 11. ed. São Paulo: Editora Revista dos Tribunais, 2010, p.525.

${ }^{21}$ THEODORO JUNIOR, Humberto. O Mandado de Segurança Segundo a Lei ${ }^{\circ} .12 .016$, de 07 de agosto de 2009. Rio de Janeiro: Forense, 2009, p.34.

${ }^{22}$ MEIRELLES, Hely Lopes; WALD, Arnoldo; MENDES, Gilmar Ferreira. Mandado de Segurança e Ações Constitucionais. 32. ed. São Paulo: Editora Malheiros, 2009, p.105.

23 BRASIL. Congresso Nacional. Lei $\mathrm{n}^{\circ}$ 12.016, de 07 de agosto 2009. Disciplina o mandado de segurança individual e coletivo e dá outras providências. Diário Oficial da União, Brasília, DF, 10.8.2009. Disponível em: < http://www.planalto.gov.br/ccivil_03/_ato2007-2010/2009/lei/112016.htm>. Acesso em: 18 ago 2014.
} 
Revista Eletrônica de Direito Processual - REDP. Volume 15. Janeiro a Junho de 2015 Periódico Semestral da Pós-Graduação Stricto Sensu em Direito Processual da UERJ. Patrono: José Carlos Barbosa Moreira. www.redp.com.br ISSN 1982-7636 PP 213-239

O Superior Tribunal Federal, sob a vigência da Lei $n^{\circ} .1 .533$ de 1951, havia consagrado essa possibilidade: "SÚMULA 304: DECISÃO DENEGATÓRIA DE MANDADO DE SEGURANÇA, NÃO FAZENDO COISA JULGADA CONTRA O IMPETRANTE, NÃO IMPEDE O USO DA AÇÃO PRÓPRIA." 24

Se o impetrante não utilizar o mandado de segurança adequadamente, não é razoável que a Administração interrompa uma licitação cujo propósito é atender o interesse público. Assim, se houver a extinção do processo, consagraram-se alternativas legais para o impetrante, de modo que a garantia de acesso ao Judiciário e o controle dos atos administrativos não sejam prejudicados. O que não se admite é a continuidade da ação constitucional sem o interesse processual útil à solução da demanda.

A doutrina esclarece esse cenário:

O mandado de segurança repressivo (destinado a desfazer ato ilegal ou abusivo) perde seu objeto se este ato e desfeito, qualquer que seja a designação reservada para o desfazimento, durante a tramitação do processo. Desaparecendo o ato, desaparece a possibilidade de que seja deferido o pedido formulado. Não há mais o que desfazer. Além disso, deixa de existir também a violação ao direito líquido e certo do impetrante.

Certo poderia haver remanescido prejuízos para ele, ocorridos durante a vigência do ato. Todavia, como estes não podem ser discutidos em mandado de segurança, esta circunstância, ainda que evidenciada, não determinaria a necessidade do respectivo prosseguimento. ${ }^{25}$

Ressalta-se que a doutrina reconhece que há exame judicial mesmo no caso de extinção do processo: "Mas ainda que a resposta do juiz se exaure na pronúncia da

\footnotetext{
${ }^{24}$ BRASIL. Supremo Tribunal Federal. Súmula 304. Data de Aprovação Sessão Plenária de 13/12/1963. Fonte de Publicação: Súmula da Jurisprudência Predominante do Supremo Tribunal Federal - Anexo ao Regimento Interno. Edição: Imprensa Nacional, 1964, p. 136.

25 DECOMAIN, Pedro Roberto. Mandado de Segurança (o tradicional, o novo e o polêmico na lei 12.016/09). São Paulo: Dialética, 2009, p.367.
} 
Revista Eletrônica de Direito Processual - REDP. Volume 15. Janeiro a Junho de 2015 Periódico Semestral da Pós-Graduação Stricto Sensu em Direito Processual da UERJ. Patrono: José Carlos Barbosa Moreira. www.redp.com.br ISSN 1982-7636 PP 213-239

carência de ação (porque não se configuram as condições da ação), terá havido exercício da função jurisdicional. "26

Há coerência entre a legislação do mandado de segurança e o Código de Processo Civil. A exordial do impetrante deverá atender as condições da ação, e o interesse de agir, necessário e útil, deve estar presente. Enquanto ação constitucional, que não comporta dilação probatória, esse requisito é claramente identificável. Não paira dúvida na doutrina. Ausente o interesse de agir, o processo deve ser extinto. Logicamente, a própria norma apresentou solução ao problema, à medida que autoriza o ingresso de outra ação judicial. Esse contexto assegura o acesso ao Judiciário e a continuidade da atividade administrativa. Os arcabouços legislativo e doutrinário trazem uma solução razoável e ponderada para o problema. Todavia a jurisprudência atual do Superior Tribunal de Justiça rompeu esse paradigma, com reflexos nos Tribunais de $2^{\circ} \mathrm{Grau}$, como será demonstrado a seguir.

\subsection{Da Jurisprudência}

A jurisprudência relativa ao tema do presente artigo está em plena evolução. Até alguns anos atrás, predominava nos Tribunais do país o entendimento de que a ausência do interesse de agir levava à extinção da ação mandamental. A partir de 2009, o Superior Tribunal de Justiça (STJ) mudou seu posicionamento, passando a decidir que a nulidade do ato na licitação contamina a adjudicação, a homologação e a celebração de contrato, impedindo a perda de objeto. Desde então, a Justiça Federal da $4^{\mathrm{a}}$ Região adotou a orientação superior. A Justiça Estadual do Rio Grande do Sul, por outro lado, ainda não é pacífica.

De acordo com o Superior Tribunal de Justiça em suas decisões anteriores a 2009, se o impetrante do mandado de segurança não obtivesse sucesso na suspensão liminar temporária do certame, a conclusão da licitação conduziria à extinção da ação pela falta de interesse processual superveniente. Ausente o interesse de agir, a ação deve ser extinta. A seguir é transcrita ementa de Acórdão de 2006:

\section{AGRAVO REGIMENTAL EM RECURSO ESPECIAL. PROCESSUAL CIVIL E ADMINISTRATIVO. VIOLAÇÃO DO}

\footnotetext{
${ }^{26}$ CINTRA, Antonio Carlos de Araujo; GRINOVER, Ada Pellegrini; DINAMARCO, Candido Rangel. Teoria Geral do Processo. 26. ed. São Paulo: Malheiros, 2010, p.280.
} 
Revista Eletrônica de Direito Processual - REDP. Volume 15. Janeiro a Junho de 2015

Periódico Semestral da Pós-Graduação Stricto Sensu em Direito Processual da UERJ.

Patrono: José Carlos Barbosa Moreira. www.redp.com.br ISSN 1982-7636 PP 213-239

ART. 535 DO CPC. INOCORRÊNCIA. LICITAÇÃO. CONSUMAÇÃO. PERDA DO OBJETO.

2. Impetrado Mandado de Segurança visando a impugnar o curso de procedimento licitatório, a superveniência de conclusão do respectivo certame, posto não lograr êxito a tentativa do recorrente de paralisa-lo via deferimento de pleito liminar, conduz à extinção do writ por falta de interesse processual superveniente, em face do fato consumado. Precedentes desta Corte: RMS 17.883 - MA, desta relatoria, Primeira Turma, DJ de 14 de novembro de 2005; RMS 17.441 RS, Relator Ministro JOÃO OTÁVIO DE NORONHA, Segunda Turma, DJ de 20 de março de 2006; RMS 17.128 - MG, Relatora Ministra ELIANA CALMON, Segunda Turma, DJ de 21 de fevereiro de 2005.

4. Ausente a utilidade do writ, requisito que, juntamente com a necessidade da tutela, compõe o interesse de agir, impõe-se a extinção do processo sem análise do mérito.

5. Agravo Regimental desprovido. ${ }^{27}$

Os fatos da referida decisão tratam de mandado de segurança interposto por uma empresa contra a sua inabilitação em uma concorrência. No caso, a licitação não foi interrompida, e o contrato estava em execução. ${ }^{28}$ Conforme o voto do Ministro Relator, a conclusão do certame licitatório revela a ausência de interesse processual no prosseguimento do feito. O interesse de agir, previsto no Artigo $3^{\circ}$ do Código de Processo Civil e composto pelo binômio necessidade-utilidade, não está presente, visto que o prosseguimento do mandando de segurança passou a não ter utilidade. Assim,

\footnotetext{
${ }^{27}$ BRASIL. Superior Tribunal de Justiça. Agravo Regimental no Recurso Especial 726031/MG. Primeira Turma. Relator Ministro Luiz Fux. Diário de Justiça, Brasília, 05 de outubro de 2006. Disponível em: $<$ https://ww2.stj.jus.br/revistaeletronica/ita.asp?registro=200500267750\&dt_publicacao=05/10/2006>. Acesso em: 18 ago 2014.

${ }^{28}$ BRASIL. Superior Tribunal de Justiça. Agravo Regimental no Recurso Especial 726031/MG. Primeira Turma. Relator Ministro Luiz Fux. Diário de Justiça, Brasília, 05 de outubro de 2006. Disponível em: $<$ https://ww2.stj.jus.br/revistaeletronica/ita.asp?registro=200500267750\&dt_publicacao=05/10/2006>. Acesso em: 18 ago 2014.
} 
Revista Eletrônica de Direito Processual - REDP. Volume 15. Janeiro a Junho de 2015 Periódico Semestral da Pós-Graduação Stricto Sensu em Direito Processual da UERJ. Patrono: José Carlos Barbosa Moreira. www.redp.com.br ISSN 1982-7636 PP 213-239 ausente a condição da ação, há carência de ação, devendo ser extinta nos termos do Artigo 267, Inciso VI do Código de Processo Civil. ${ }^{29}$

Após a edição da Lei Federal $n^{\circ} .12 .016$ de 07 de agosto de 2009, o STJ modificou o seu entendimento sobre o assunto. Um dos primeiros acórdãos que romperam esse paradigma foi publicado em 10 de setembro de 2009. Trata-se de recurso especial em mandado de segurança, impetrado por empresa contra ilegalidades que viciaram edital de um certame, cujo objeto já havia sido adjudicado:

ADMINISTRATIVO E PROCESSUAL CIVIL. LICITAÇÃO. MANDADO DE SEGURANÇA. IMPUGNAÇÃO DE EDITAL. ILEGALIDADES. ADJUDICAÇÃO SUPERVENIENTE. PERDA DE OBJETO. NÃO-CARACTERIZAÇÃO.

1. O mandado de segurança voltou-se contra ilegalidades que viciavam o edital do certame, motivo pelo qual superveniente adjudicação não dá ensejo à perda de objeto - pois é evidente que, se o procedimento licitatório é eivado de nulidades de pleno direito desde seu início, a adjudicação e a posterior celebração do contrato também o são (art. 49, $\S 2^{\circ}$, da Lei $n$. 8.666/93).

2. Entendimento diverso equivaleria a dizer que a própria Administração Pública, mesmo tendo dado causa às ilegalidades, pode convalidar administrativamente o procedimento, afastando-se a possibilidade de controle de arbitrariedades pelo Judiciário (malversação do art. 5\%, inc. XXXV, da Constituição da República vigente).

3. Recurso especial não provido. ${ }^{30}$

Conforme o voto proferido na decisão, a nulidade da licitação atinge a adjudicação e o contrato, não havendo perda de objeto ${ }^{31}$. A sucinta fundamentação do acórdão serviu de supedâneo, desde então, para as demais decisões da Corte.

\footnotetext{
${ }^{29}$ Idem. Ibidem.

30 BRASIL. Superior Tribunal de Justiça. Recurso Especial 1.059.501-MG. Segunda Turma. Relator Ministro Mauro Campbell Marques. Diário de Justiça, Brasília, 10 de setembro de 2009. Disponível em:< https://ww2.stj.jus.br/revistaeletronica/ita.asp?registro=200801067652\&dt_publicacao=10/09/2009>. Acesso em: 18 ago 2014.
} 
Revista Eletrônica de Direito Processual - REDP. Volume 15. Janeiro a Junho de 2015 Periódico Semestral da Pós-Graduação Stricto Sensu em Direito Processual da UERJ. Patrono: José Carlos Barbosa Moreira. www.redp.com.br ISSN 1982-7636 PP 213-239

Em decisão semelhante de 2011, oriunda de agravo regimental em pedido de suspensão de liminar em mandado de segurança, impetrado por empresa contra a inabilitação de pregão presencial, cujo objeto já havia sido adjudicado e o contrato foi celebrado, a fundamentação do voto foi semelhante à decisão anterior: "A superveniente adjudicação não importa na perda de objeto do mandado de segurança, pois se o procedimento licitatório está eivado de nulidades, estas também contaminam a adjudicação e posterior celebração do contrato". ${ }^{32}$

As decisões focam na ilegalidade da licitação enquanto nulidade absoluta que contamina todas as etapas do processo administrativo. Nos anos seguintes, a jurisprudência permanece uníssona e torna-se orientação da Corte Especial:

Com efeito, a decisão ora atacada adotou a orientação da Corte Especial do STJ, a qual entende que "a superveniente adjudicação não importa na perda de objeto do mandado de segurança, pois se o certame está eivado de nulidades, estas também contaminam a adjudicação e posterior celebração do contrato" (AgRg na SS 2.370/PE, Rel. Min. Ari Pargendler, Corte Especial, DJe 23.9.2011). No mesmo sentido: REsp 1.128.271/AM, Rel. Min; Castro Meira, Segunda Turma, DJe 25.11.2009; e REsp 1.059.501/MG, Rel. Min; Mauro Campbell Marques, Segunda Turma, DJe 10.9.2009. ${ }^{33}$

O Tribunal Regional da $4^{\text {a }}$ Região adotou essa orientação. Conforme ementa de Acórdão de 2012, a Corte Federal fez referência ao fato do STJ ter-se manifestado diversas vezes no sentido de que a adjudicação e a homologação não implicam a perda do objeto:

\footnotetext{
${ }^{31}$ Idem. Ibidem.

32 BRASIL. Superior Tribunal de Justiça. Agravo Regimental na Suspensão de Segurança 2.370-PE. Corte Especial. Relator Ministro Ari Pargendler. Diário de Justiça, Brasília, 23 de setembro de 2011. Disponível em: $<$ https://ww2.stj.jus.br/revistaeletronica/ita.asp?registro=201001170158\&dt_publicacao=23/09/2011>. Acesso em: 18 ago 2014.

33 BRASIL. Superior Tribunal de Justiça. Agravo Regimental no Recurso em Mandado de Segurança 39.529-ES. Segunda Turma. Relator Ministro Herman Benjamin. Diário de Justiça, Brasília, 10 de maio de 2013.2 Disponível em: $<$ https://ww2.stj.jus.br/revistaeletronica/ita.asp?registro=201200193349\&dt_publicacao=31/10/2012>. Acesso em: 18 ago 2014.
} 
Revista Eletrônica de Direito Processual - REDP. Volume 15. Janeiro a Junho de 2015

Periódico Semestral da Pós-Graduação Stricto Sensu em Direito Processual da UERJ.

Patrono: José Carlos Barbosa Moreira. www.redp.com.br ISSN 1982-7636 PP 213-239

ADMINISTRATIVO. MANDADO DE SEGURANÇA. LICITAÇÃO CONCLUÍDA. ADJUDICAÇÃO, CONTRATAÇÃO E EXECUÇÃO. AUSÊNCIA SUPERVENIENTE DO INTERESSE DE AGIR. PERDA DE OBJETO. NÃO VERIFICAÇÃO. ILEGALIDADE NO PROCEDIMENTO. INEXISTENCIA. JUNTADA DE DOCUMENTOS COMPLEMENTARES. PROCESSO DIALÉTICO. PROTEÇÃO DA CONFIANÇA.

1. Na esteira do entendimento sedimentado no âmbito do Superior Tribunal de Justiça, a adjudicação do objeto licitado não importa na ausência superveniente do interesse de agir na ação mandamental, pois se o certame está eivado de nulidades, estas também contaminam a adjudicação e a posterior celebração do contrato. Precedente. ${ }^{34}$

De acordo com o julgamento, se a nulidade fosse convalidada, estar-se-ia impedindo que o Poder Judiciário analisasse a legalidade dos atos administrativos levados a cabo na licitação. ${ }^{35}$

Em outra recente decisão de 2014, o Tribunal Federal passou a fazer referência ao entendimento sedimentado da Corte Especial, conforme ementa de Acórdão oriundo de mandado de segurança impetrado contra ato que habilitou empresa em uma licitação:

ADMINISTRATIVO. MANDADO DE SEGURANÇA. PREGÃO ELETRÔNICO. REJEIÇÃO DA INTENÇÃO RECURSAL PELO PREGOEIRO. NULIDADE DO ATO. REABERTURA DO

34 BRASIL. Tribunal Regional Federal da $4^{\mathrm{a}}$ Região. Reexame Necessário Cível 500081580.2012.404.7100/RS. Quarta Turma. Relator Desembargador Luís Alberto D'Azevedo Aurvalle. D.E. $16 / 11 / 2012$. Disponível em:

http://jurisprudencia.trf4.jus.br/pesquisa/inteiro_teor.php?orgao=1\&documento=5440696>. Acesso em: 18 ago 2014.

35 BRASIL. Tribunal Regional Federal da $4^{\mathrm{a}}$ Região. Reexame Necessário Cível 500081580.2012.404.7100/RS. Quarta Turma. Relator Desembargador Luís Alberto D'Azevedo Aurvalle. D.E. $16 / 11 / 2012$. Disponível em:

http://jurisprudencia.trf4.jus.br/pesquisa/inteiro_teor.php?orgao $=1 \&$ documento $=5440696>$. Acesso em: 18 ago 2014. 
Revista Eletrônica de Direito Processual - REDP. Volume 15. Janeiro a Junho de 2015

Periódico Semestral da Pós-Graduação Stricto Sensu em Direito Processual da UERJ.

Patrono: José Carlos Barbosa Moreira. www.redp.com.br ISSN 1982-7636 PP 213-239

PRAZO RECURSAL. ADJUDICAÇÃO. NÃO HÁ PERDA DE

OBJETO DO MANDAMUS.

- A superveniente adjudicação não importa na perda de objeto do mandado de segurança, pois se o certame está eivado de nulidades, estas também contaminam a adjudicação e posterior celebração do contrato. ${ }^{36}$

Por sua vez, o Tribunal de Justiça do Estado do Rio Grande do Sul não adotou pacificamente o novo entendimento da Corte Especial. A 22a Câmara Cível do Tribunal Estadual acolheu o posicionamento do STJ, concluindo não haver perda de objeto do mandado de segurança após a adjudicação. Em caso no qual o impetrante atacou ato do Presidente de uma Comissão de Licitação, cujo contrato já havia sido assinado, a Corte, em 01/04/2013, assim decidiu:

AGRAVO DE INSTRUMENTO. LICITAÇÃO E CONTRATO ADMINISTRATIVO. MANDADO DE SEGURANÇA. COMPROVAÇÃO INCOMPLETA DE CAPACITAÇÃO. LIMINAR MANTIDA. ADJUDICAÇÃO DO OBJETO DO CERTAME. PERDA DO OBJETO. INOCORRÊNCIA.

À luz de recente posicionamento do e. STJ, não há perda do objeto do mandado de segurança quando da adjudicação. Preliminar afastada. ${ }^{37}$

$\mathrm{Na}$ fundamentação da decisão, o Tribunal concluiu, com base na Corte Especial, que a impetração da ordem após a adjudicação não implica perda de objeto, visto que a nulidade contamina as demais fases do certame. Todavia, o voto critica o

\footnotetext{
${ }^{36}$ BRASIL. Tribunal Regional Federal da $4^{\mathrm{a}}$ Região. Apelação/Reexame Necessário Cível 504672244.2013.404.7100/RS. Terceira Turma. Relator Desembargador Roger Raupp rios. D.E. 11/07/2014. Disponível em: http://jurisprudencia.trf4.jus.br/pesquisa/inteiro_teor.php?orgao $=1 \&$ documento $=6751258>$. Acesso em: 18 ago 2014.

${ }^{37}$ BRASIL. Tribunal de Justiça do Estado do Rio Grande do Sul. Agravo de Instrumento 70052889680. $22^{\mathrm{a}}$ Câmara Cível. Relator Desembargador Eduardo Kraemer. D.J. 01/04/2013. Disponível em: $<$ http://www1.tjrs.jus.br/site_php/consulta/download/exibe_documento_att.php?ano=2013\&codigo $=2$ 59100>. Acesso em: 18 ago 2014.
} 
Revista Eletrônica de Direito Processual - REDP. Volume 15. Janeiro a Junho de 2015 Periódico Semestral da Pós-Graduação Stricto Sensu em Direito Processual da UERJ. Patrono: José Carlos Barbosa Moreira. www.redp.com.br ISSN 1982-7636 PP 213-239 entendimento da Corte Especial ${ }^{38}$ : “Assim, ainda que pairem dúvidas acerca da aplicação prática do novel posicionamento da superior instância, supero a prefacial.”

Entretanto, em decisão publicada em 23 de maio de 2013, houve divergência na mesma Câmara sobre o assunto:

AGRAVO. MANDADO DE SEGURANÇA. LICITAÇÃO E CONTRATO ADMINISTRATIVO. NÃO PARTICIPAÇÃO PELO IMPETRANTE. PROSSEGUIMENTO DO CERTAME. ADJUDICAÇÃO DO OBJETO PELA VENCEDORA. PERDA DO OBJETO DA AÇÃO.

$O$ procedimento licitatório encerra-se com a homologação $e$ adjudicação do objeto licitado pelo vencedor. Perda do objeto do mandamus configurada em face da adjudicação do objeto pela empresa vencedora. Precedentes desta Corte e do STJ. ${ }^{39}$

$\mathrm{O}$ caso trata de mandado de segurança impetrado contra ato em licitação de concessão de serviço de transporte. No julgamento, dois desembargadores votaram pela perda de objeto, sustentando que:

Ocorre que, não tendo sido efetivamente resguardado provisoriamente o direito pleiteado pela impetrante, sobretudo considerando que a medida liminar foi indeferida, tem-se que a ação perdeu seu objeto.

Ora, quando a segurança questiona o processo de licitação, não subsiste seu objeto depois de extinto o certame, com a adjudicação do objeto ao vencedor e de sua contratação.

\footnotetext{
${ }^{38}$ BRASIL. Tribunal de Justiça do Estado do Rio Grande do Sul. Agravo de Instrumento 70052889680. $22^{\mathrm{a}}$ Câmara Cível. Relator Desembargador Eduardo Kraemer. D.J. 01/04/2013. Disponível em: $<$ http://www1.tjrs.jus.br/site_php/consulta/download/exibe_documento_att.php?ano=2013\&codigo=2 59100>. Acesso em: 18 ago 2014.

${ }^{39}$ BRASIL. Tribunal de Justiça do Estado do Rio Grande do Sul. Agravo Regimental 70053155453. 22 ${ }^{\mathrm{a}}$ Câmara Cível. Relator Desembargador Eduardo Kraemer. D.J. 22/05/2013. Disponível em: < http://wwwl.tjrs.jus.br/site_php/consulta/download/exibe_documento_att.php?ano=2013\&codigo $=77850$ 9>. Acesso em: 18 ago 2014.
} 
Revista Eletrônica de Direito Processual - REDP. Volume 15. Janeiro a Junho de 2015

Periódico Semestral da Pós-Graduação Stricto Sensu em Direito Processual da UERJ.

Patrono: José Carlos Barbosa Moreira. www.redp.com.br ISSN 1982-7636 PP 213-239

Portanto, o presente mandado de segurança deveria mesmo ser extinto sem exame de mérito. ${ }^{40}$

Por outro lado, a Desembargadora Presidente da Câmara votou segundo o entendimento do STJ, concluindo que não havia perda de objeto pelo encerramento da licitação e assinatura do contrato. ${ }^{41}$

Em outra decisão relevante, publicada em 08 de julho 2013, a 22 Câmara concluiu pela perda de objeto:

APELAÇÃO. MANDADO DE SEGURANÇA. LICITAÇÃO E CONTRATO ADMINISTRATIVO. PREGÃO ELETRÔNICO $N^{\circ}$ 307/2011 DO DMAE. ALTERAÇÃO DE DATA DO CERTAME REPUTADA ILEGAL PELA APELANTE. ADJUDICAÇÃO DO OBJETO PELA VENCEDORA. CONSEQUENTE PERDA DO OBJETO DA AÇÃO. O procedimento licitatório encerra-se com a homologação e adjudicação do objeto licitado pelo vencedor. Caso concreto em que a pretensão visa unicamente à declaração de nulidade da retomada do Pregão $n^{\circ}$ 307/2011 do DMAE. Perda do objeto configurada em face da adjudicação do objeto pela empresa vencedora. Precedentes desta Corte. PROCESSO EXTINTO SEM RESOLUÇÃO DE MÉRITO, PREJUDICADO O EXAME DO APELO. DECISÃO MONOCRÁTICA. ${ }^{42}$

Nos termos do voto do relator, não houve julgamento vinculativo das decisões do STJ e, se o direito não foi resguardado provisoriamente e se o contrato já foi assinado, a ação perdeu seu objeto. ${ }^{43}$ Todavia, a mesma Câmara Cível, em 22 de

\footnotetext{
${ }^{40}$ BRASIL. Tribunal de Justiça do Estado do Rio Grande do Sul. Agravo Regimental 70053155453. 22 ${ }^{\mathrm{a}}$ Câmara Cível. Relator Desembargador Eduardo Kraemer. D.J. 22/05/2013. Disponível em: < http://www1.tjrs.jus.br/site_php/consulta/download/exibe_documento_att.php?ano=2013\&codigo $=77850$ 9>. Acesso em: 18 ago 2014.

${ }^{41}$ Idem. Ibidem.

42 BRASIL. Tribunal de Justiça do Estado do Rio Grande do Sul. Agravo Regimental 70054009840. 22 ${ }^{\mathrm{a}}$ Câmara Cível. Relator Desembargador Eduardo Kraemer. D.J. 05/07/2013. Disponível em: < http://www1.tjrs.jus.br/site_php/consulta/download/exibe_documento_att.php?ano=2013\&codigo $=10780$ 01>. Acesso em: 18 ago 2014.

${ }^{43}$ Idem. Ibidem.
} 
Revista Eletrônica de Direito Processual - REDP. Volume 15. Janeiro a Junho de 2015 Periódico Semestral da Pós-Graduação Stricto Sensu em Direito Processual da UERJ. Patrono: José Carlos Barbosa Moreira. www.redp.com.br ISSN 1982-7636 PP 213-239 novembro de 2013, mudou seu posicionamento, passando a decidir que não há perda do objeto do mandado de segurança após a homologação, adjudicação e celebração do contrato oriundo de licitação:

$\begin{array}{lccccc}\text { MANDADO } & \text { DE } & \text { SEGURANÇA. } & \text { LICITAÇÃO. } & \text { OBRA } & \text { E } \\ \text { SERVIÇOS } & \text { DE } & \text { ENGENHARIA. } & \text { PERDA } & \text { DO } & \text { OBJETO. } \\ \text { INABILITAÇÃO. } & \text { CLASSIFICAÇÃO. } & 2^{\circ} \text { LUGAR. } & \text { PERDA DO } \\ \text { OBJETO. EDITAL. } & \text { QUALIFICAÇÃO } & \text { TECNICA } \\ \text { OPERACIONAL. EMPRESA. ATETADOS. } & \text { EMPRESA. }\end{array}$
PROFISSIONAL.

1. A homologação e a adjudicação do objeto da licitação ao vencedor, bem como a posterior celebração do contrato não acarreta a perda do objeto do mandado de segurança impetrado contra o ato administrativo que indeferira a habilitação da impetrante. Jurisprudência do STJ. Hipótese, ainda, em que a impetrante ficou classificada em segundo lugar num dos lotes da concorrência, o que gera legítima expectativa de contratação na hipótese do art. 24, inciso IX, da Lei $n^{o} 8.666 / 93 .{ }^{44}$

No caso, que trata de mandado impetrado contra ato que inabilitou empresa em uma concorrência pública, cujo contrato já havia sido celebrado, a decisão fundamentou-se nos precedentes da Corte Especial. ${ }^{45}$ A partir de então, a $22^{\text {a }}$ Câmara Cível manteve seu posicionamento nos termos dos precedentes do STJ. ${ }^{46}$

Nesse mesmo diapasão, a $21^{\text {a }}$ Câmara Cível, em 2014, também seguiu o STJ, concluindo não haver perda de objeto nos casos de encerramento do certame e de celebração de contrato:

\footnotetext{
${ }^{44}$ BRASIL. Tribunal de Justiça do Estado do Rio Grande do Sul. Mandado de Segurança 70056366719. $22^{a}$ Câmara Cível. Relatora Desembargadora Maria Isabel de Azevedo Souza. D.J. 21/11/2013. Disponível $<$ http://www1.tjrs.jus.br/site_php/consulta/download/exibe_documento_att.php?ano=2013\&codigo=2027 396>. Acesso em: 18 ago 2014 .

45 Idem. Ibidem.

46 BRASIL. Tribunal de Justiça do Estado do Rio Grande do Sul. Mandado de Segurança 70057240079. 22 a ${ }^{\text {a }}$ ara Cível. Relatora Desembargadora Maria Isabel de Azevedo Souza. D.J. 03/12/2013. Disponível $<$ http://www1.tjrs.jus.br/site_php/consulta/download/exibe_documento_att.php?ano=2013\&codigo $=2132$ 461>. Acesso em: 18 ago 2014.
} 
Revista Eletrônica de Direito Processual - REDP. Volume 15. Janeiro a Junho de 2015

Periódico Semestral da Pós-Graduação Stricto Sensu em Direito Processual da UERJ.

Patrono: José Carlos Barbosa Moreira. www.redp.com.br ISSN 1982-7636 PP 213-239

\begin{tabular}{lccccr} 
APELAÇÁO & CÍVEL. & LICITAÇÃO & E & \multicolumn{2}{c}{ CONTRATO } \\
ADMINISTRATIVO. & MANDADO & DE & SEGURANÇA \\
IMPETRADO & POR & LICITANTE & OBJETIVANDO & $A$ \\
HABILITAÇÃO & E A & DECLARAÇÃO & DE & VENCEDO-RA & EM \\
PROCEDIMENTO LICITATÓRIO. & ENCERRAMENTO & DO \\
CERTAME. CONTRATAÇÃO & EFETUADA. & PERDA & DO \\
OBJETO DO MANDAMUS. INOCORRENCIA... &
\end{tabular}

Não há consenso em relação ao tema nas Câmara Cíveis. A $1^{\mathrm{a}}$ Câmara Cível sequer faz referência ao posicionamento do STJ em seus acórdãos, concluindo que, encerrado o procedimento licitatório, há perda de objeto:

AGRAVO DE INSTRUMENTO. LICITAÇÃO E CONTRATO ADMINISTRATIVO. MANDADO DE SEGURANÇA. LIMINAR CONCEDIDA PARA SUSPENSÃO DO PROCEDIMENTO LICITATÓRIO. PROCEDIMENTO LICITATÓRIO ENCERRADO. PERDA DE OBJETO.

Encerrado o procedimento licitatório impugnado, bem como realizado o respectivo contrato, a extinção do feito, sem resolução do mérito, em face da perda de objeto, é a medida que se impõe.

RECURSO PROVIDO. MANDADO DE SEGURANÇA EXTINTO, FACE À PERDA DE OBJETO. ${ }^{48}$

Nota-se que o tema debatido na jurisprudência não é pacífico. No STJ, não há súmula, nem tampouco há jurisprudência decorrente de recurso repetitivo nos termos do Artigo 543-C do Código de Processo Civil. O entendimento é relativamente recente e

\footnotetext{
${ }^{47}$ BRASIL. Tribunal de Justiça do Estado do Rio Grande do Sul. Apelação Cível 70057129983. 21 ${ }^{\text {a }}$ Câmara Cível. Relator Desembargador Francisco José Moesch. D.J. 22/01/2014. Disponível em: $<$ http://www1.tjrs.jus.br/site_php/consulta/download/exibe_documento_att.php?ano=2013\&codigo $=2267$ 101>. Acesso em: 18 ago 2014.

${ }^{48}$ BRASIL. Tribunal de Justiça do Estado do Rio Grande do Sul. Agravo de Instrumento 70059017616. $1^{\text {a }}$ Câmara Cível. Relator Desembargador Sérgio Luiz Grassi Beck. D.J. 24/04/2014. Disponível em: $<$ http://www1.tjrs.jus.br/site_php/consulta/download/exibe_documento_att.php?ano=2014\&codigo $=3547$ 48>. Acesso em: 18 ago 2014.
} 
Revista Eletrônica de Direito Processual - REDP. Volume 15. Janeiro a Junho de 2015 Periódico Semestral da Pós-Graduação Stricto Sensu em Direito Processual da UERJ. Patrono: José Carlos Barbosa Moreira. www.redp.com.br ISSN 1982-7636 PP 213-239 ainda não há uma aplicação harmônica entre o Tribunal Regional Federal da $4^{\mathrm{a}}$ Região e o Tribunal de Justiça do Estado do Rio Grande do Sul. Verifica-se que o STJ prima pela proteção da legalidade da licitação. Todavia, como apontado pelo Tribunal de Justiça, há questões práticas sem respostas no caso de aplicação do entendimento da Corte Especial.

Afinal, a consolidação da tese da Corte Superior nos demais Tribunais poderá trazer graves consequências à Administração Pública. Na licitação que não for suspensa por liminar, o gestor público terá que ponderar entre o seu prosseguimento ou a sua anulação. Tal medida não parece razoável, visto que, se houve a licitação, se presume o interesse público pela sua conclusão. É evidente que não se está ventilando a hipótese de dar prosseguimento a um certame ilegal. Discute-se, sim, a utilidade do mandado de segurança nesses casos. A própria lei e a doutrina autorizam sua extinção, mas o posicionamento dominante do Judiciário vai de encontro à essa possibilidade.

Ora, o acesso ao Judiciário é assegurado através de outras espécies de ações nas quais poderá ser examinada a legalidade do ato, inclusive com dilação probatória e com pedido indenizatório. Nesse contexto, a jurisprudência dominante não está em harmonia com legislação, cabendo ao Administrador adequar a gestão pública ao risco judicial.

\section{Conclusão}

Não paira dúvida acerca da possibilidade de controle judicial do ato administrativo na licitação pública. Todavia, pondera-se sobre o seu alcance no mandado de segurança. Sob a égide da nova corrente jurisprudencial do Superior Tribunal de Justiça, qualquer licitação, ainda que a Administração Pública já esteja executando o contrato dela decorrente, poderá ser anulada retroativamente.

As decisões da Corte Especial vão de encontro à legislação que expressamente autoriza a extinção do processo sem resolução do mérito quando ausente o interesse de agir. Se não houver liminar no processo, não é razoável que a Administração interrompa sua atividade indefinidamente até o julgamento final. O mandamus, enquanto remédio célere, não é a ação adequada nesse caso e deveria ser extinto. Não se trata de restringir o acesso ao Judiciário, nem tampouco de impedir o controle do ato administrativo, mas 
Revista Eletrônica de Direito Processual - REDP. Volume 15. Janeiro a Junho de 2015 Periódico Semestral da Pós-Graduação Stricto Sensu em Direito Processual da UERJ. Patrono: José Carlos Barbosa Moreira. www.redp.com.br ISSN 1982-7636 PP 213-239 sim da utilização da ação mais adequada à causa. Afinal, a própria lei que autoriza a extinção, permite o ajuizamento de outra espécie de ação.

Para que haja a correta avaliação da legalidade do ato, devem ser levados em consideração dois planos distintos, o do direito material e o do direito processual. Assim, é possível concluir que a impetrante não terá sua demanda atendida através da ação constitucional, mas a legislação lhe assegura o acesso ao Judiciário através da interposição de outras ações judiciais.

Nesse tipo de situação, as decisões do Tribunal de Justiça que concluem pela perda de objeto denotam um entendimento mais ponderado da realidade. O mandado de segurança, enquanto remédio constitucional célere, não se presta para solucionar esse tipo de lide. Há ausência de interesse de agir. Cabe ao requerente ajuizar ação indenizatória, visto que os fatos já estão consumados. O entendimento do Superior Tribunal de Justiça é recente e, ainda que adotado pelo Tribunal Regional da $4^{\text {a }}$ Região e parcialmente pelo Tribunal de Justiça do Estado do Rio Grande do Sul, não se consolidou em súmula, nem tampouco jurisprudência decorrente de recurso repetitivo. É necessário o enfrentamento de situações práticas nas quais a anulação dos atos não terá utilidade alguma, por exemplo, quando uma obra já tiver sido concluída. Nesse caso, somente se poderia cogitar de ação ordinária indenizatória. Dessa maneira, ficará resguardada também a atribuição do Poder Judiciário de examinar o ato.

A partir desse posicionamento divergente, poderia ser construída nova corrente jurisprudencial que analisasse com maior profundidade a matéria, confrontando objetivamente a tese da Corte Especial com os dispositivos legais e a doutrina que sustentam a extinção da ação. A Constituição Federal protege concomitantemente o direito do impetrante e o interesse público. Se o impetrante não utilizar o mandado de segurança adequadamente, não é razoável que a Administração interrompa uma licitação cujo propósito é atender a sua finalidade pública. Mas, se houver a extinção do processo, há alternativas processuais para o impetrante, de modo que a garantia de acesso ao Judiciário e o controle dos atos administrativos não sejam prejudicados. $\mathrm{O}$ que não se admite é a continuidade da ação constitucional sem o interesse processual útil à solução da demanda.

Ora, é imensa a insegurança jurídica trazida ao exercício da atividade pública nas licitações. O que não se pode perder de vista é o prejuízo que pode ser causado à Administração e consequentemente à sociedade com a interrupção de um serviço 
Revista Eletrônica de Direito Processual - REDP. Volume 15. Janeiro a Junho de 2015 Periódico Semestral da Pós-Graduação Stricto Sensu em Direito Processual da UERJ. Patrono: José Carlos Barbosa Moreira. www.redp.com.br ISSN 1982-7636 PP 213-239 público em andamento. Se a legalidade do ato deve ser protegida, a continuidade da prestação do serviço público também. Ainda que o impetrante não tenha sua demanda atendida através da ação constitucional, a legislação lhe assegura o acesso ao Judiciário através da interposição de outras ações judiciais.

Enfim, enquanto perdurar a posição do Superior Tribunal de Justiça, para a redução do risco judicial, caberá ao Administrador Público aprimorar a fundamentação dos atos para protegê-lo de questionamentos, ciente de que, por enquanto, o certame poderá ser anulado retroativamente.

\section{REFERÊNCIAS BIBLIOGRÁFICAS}

ALVIM, J. E. Carreira. Comentários à Nova Lei do Mandado de Segurança - Lei 12016/09. 1. ed. Curitiba: Juruá, 2009.

CINTRA, Antonio Carlos de Araujo; GRINOVER, Ada Pellegrini; DINAMARCO, Candido Rangel. Teoria Geral do Processo. 26. ed. São Paulo: Malheiros, 2010.

DECOMAIN, Pedro Roberto. Mandado de Segurança (o tradicional, o novo e o polêmico na lei 12.016/09). São Paulo: Dialética, 2009.

MARINONI, Luiz Guilherme. Teoria Geral do Processo. 4. ed. São Paulo: Editora Revista dos Tribunais, 2010. v. 1.

MEIRELLES, Hely Lopes; WALD, Arnoldo; MENDES, Gilmar Ferreira. Mandado de Segurança e Ações Constitucionais. 32. ed. São Paulo: Editora Malheiros, 2009.

NERY JUNIOR, Nelson; NERY, Rosa Maria de Andrade. Código de Processo Civil Comentado e Legislação Vigente. 11. ed. São Paulo: Editora Revista dos Tribunais, 2010.

RIGOLIN, Ivan Barbosa; BOtTINO, Marco Tullio. Manual Prático de Licitações. 5. ed. São Paulo: Saraiva, 2005.

SANTOS, Ernane Fidélis dos. Manual de Direito Processual Civil. São Paulo: Saraiva, 1998. v. 1.

THEODORO JÚNIOR, Humberto. Curso de Direito Processual Civil. Rio de Janeiro: Forense, 1999. v. 1.

THEODORO JUNIOR, Humberto. O Mandado de Seguranca Segundo a Lei $\mathbf{n}^{\mathbf{0}} \mathbf{. 1 2 . 0 1 6}$, de 07 de agosto de 2009. Rio de Janeiro: Forense, 2009. 
Revista Eletrônica de Direito Processual - REDP. Volume 15. Janeiro a Junho de 2015 Periódico Semestral da Pós-Graduação Stricto Sensu em Direito Processual da UERJ. Patrono: José Carlos Barbosa Moreira. www.redp.com.br ISSN 1982-7636 PP 213-239 WAMBIER, Luiz Rodrigues (Coord). Curso avançado de processo civil: teoria geral do processo e processo de conhecimento. 10. ed. São Paulo: Editora Revista dos Tribunais, 2008. v.1.

\section{Jurisprudência}

BRASIL. Supremo Tribunal Federal. Súmula 304. Data de Aprovação Sessão Plenária de 13/12/1963. Fonte de Publicação Súmula da Jurisprudência Predominante do Supremo Tribunal Federal - Anexo ao Regimento Interno. Edição: Imprensa Nacional, 1964, p. 136.

BRASIL. Superior Tribunal de Justiça. Agravo Regimental no Recurso Especial 726031/MG. Primeira Turma. Relator Ministro Luiz Fux. Diário de Justiça, Brasília, 05 de outubro de $2006 . \quad$ Disponível em: $<$ https://ww2.stj.jus.br/revistaeletronica/ita.asp?registro=200500267750\&dt_publicacao $=05 / 10 / 2006>$. Acesso em: 18 ago 2014 .

BRASIL. Superior Tribunal de Justiça. Recurso Especial 1.059.501-MG. Segunda Turma. Relator Ministro Mauro Campbell Marques. Diário de Justiça, Brasília, 10 de setembro de 2009. Disponível em:< https://ww2.stj.jus.br/revistaeletronica/ita.asp?registro=200801067652\&dt_publicacao= 10/09/2009>. Acesso em: 18 ago 2014.

BRASIL. Superior Tribunal de Justiça. Agravo Regimento na Suspensão de Segurança 2.370-PE. Corte Especial. Relator Ministro Ari Pargendler. Diário de Justiça, Brasília, 23 de setembro de 2011. Disponível em: $<$ https://ww2.stj.jus.br/revistaeletronica/ita.asp?registro=201001170158\&dt_publicacao =23/09/2011>. Acesso em: 18 ago 2014 .

BRASIL. Superior Tribunal de Justiça. Agravo Regimental no Recurso em Mandado de Segurança 39.529-ES. Segunda Turma. Relator Ministro Herman Benjamin. Diário de Justiça, Brasília, 10 de maio de 2013. Disponível em: $<$ https://ww2.stj.jus.br/revistaeletronica/ita.asp?registro=201200193349\&dt_publicacao $=31 / 10 / 2012>$. Acesso em: 18 ago 2014 .

BRASIL. Tribunal Regional Federal da $4^{\mathrm{a}}$ Região. Reexame Necessário Cível 500081580.2012.404.7100/RS. Quarta Turma. Relator Desembargador Luís Alberto D'Azevedo 
Revista Eletrônica de Direito Processual - REDP. Volume 15. Janeiro a Junho de 2015 Periódico Semestral da Pós-Graduação Stricto Sensu em Direito Processual da UERJ. Patrono: José Carlos Barbosa Moreira. www.redp.com.br ISSN 1982-7636 PP 213-239

\begin{tabular}{lllll}
\hline \hline Aurvalle. & D.E. & $16 / 11 / 2012$. & Disponível & em:
\end{tabular}

http://jurisprudencia.trf4.jus.br/pesquisa/inteiro_teor.php?orgao=1\&documento=544069 6>. Acesso em: 18 ago 2014.

BRASIL. Tribunal Regional Federal da $4^{\mathrm{a}}$ Região. Apelação/Reexame Necessário Cível 5046722-44.2013.404.7100/RS. Terceira Turma. Relator Desembargador Roger Raupp rios. D.E. 11/07/2014. Disponível em: < http://jurisprudencia.trf4.jus.br/pesquisa/inteiro_teor.php?orgao $=1 \&$ documento $=675125$ 8>. Acesso em: 18 ago 2014.

BRASIL. Tribunal de Justiça do Estado do Rio Grande do Sul. Agravo de Instrumento 70052889680. 22 $2^{\mathrm{a}}$ Câmara Cível. Relator Desembargador Eduardo Kraemer. D.J. $01 / 04 / 2013$. Disponível em:

http://www1.tjrs.jus.br/site_php/consulta/download/exibe_documento_att.php?ano=201 $3 \&$ codigo $=259100>$. Acesso em: 18 ago 2014.

BRASIL. Tribunal de Justiça do Estado do Rio Grande do Sul. Agravo Regimental 70053155453. 22 $2^{\mathrm{a}}$ Câmara Cível. Relator Desembargador Eduardo Kraemer. D.J. $22 / 05 / 2013$. Disponível em:

http://www1.tjrs.jus.br/site_php/consulta/download/exibe_documento_att.php?ano=201 $3 \&$ codigo $=778509>$. Acesso em: 18 ago 2014.

BRASIL. Tribunal de Justiça do Estado do Rio Grande do Sul. Agravo Regimental 70054009840. 22 $2^{\mathrm{a}}$ Câmara Cível. Relator Desembargador Eduardo Kraemer. D.J. 05/07/2013. Disponível em:

http://www1.tjrs.jus.br/site_php/consulta/download/exibe_documento_att.php?ano=201 $3 \&$ codigo $=1078001>$. Acesso em: 18 ago 2014.

BRASIL. Tribunal de Justiça do Estado do Rio Grande do Sul. Mandado de Segurança 70056366719. 22 ${ }^{\mathrm{a}}$ Câmara Cível. Relatora Desembargadora Maria Isabel de Azevedo Souza. D.J. 21/11/2013. Disponível em: $<$ http://www1.tjrs.jus.br/site_php/consulta/download/exibe_documento_att.php?ano=20 13\&codigo=2027396>. Acesso em: 18 ago 2014.

BRASIL. Tribunal de Justiça do Estado do Rio Grande do Sul. Mandado de Segurança 70057240079. 22 $2^{\mathrm{a}}$ Câmara Cível. Relatora Desembargadora Maria Isabel de Azevedo Souza. D.J. 03/12/2013. Disponível em: $<$ http://www1.tjrs.jus.br/site_php/consulta/download/exibe_documento_att.php?ano=20 $13 \&$ codigo $=2132461>$. Acesso em: 18 ago 2014. 
Revista Eletrônica de Direito Processual - REDP. Volume 15. Janeiro a Junho de 2015 Periódico Semestral da Pós-Graduação Stricto Sensu em Direito Processual da UERJ. Patrono: José Carlos Barbosa Moreira. www.redp.com.br ISSN 1982-7636 PP 213-239 BRASIL. Tribunal de Justiça do Estado do Rio Grande do Sul. Apelação Cível 70057129983. 21 Câmara Cível. Relator Desembargador Francisco José Moesch. D.J. $22 / 01 / 2014$. Disponível em: $<$ http://www1.tjrs.jus.br/site_php/consulta/download/exibe_documento_att.php?ano=20 13\&codigo=2267101>. Acesso em: 18 ago 2014.

BRASIL. Tribunal de Justiça do Estado do Rio Grande do Sul. Apelação Cível 70059017616. 1 ${ }^{a}$ Câmara Cível. Relator Desembargador Sérgio Luiz Grassi Beck. D.J. $24 / 04 / 2014$. Disponível em: $<$ http://www1.tjrs.jus.br/site_php/consulta/download/exibe_documento_att.php?ano=20 14\&codigo $=354748>$. Acesso em: 18 ago 2014.

\section{Legislação}

BRASIL. Assembleia Nacional Constituinte. Constituição da República Federativa do Brasil de 1988. Diário Oficial da União, Brasília, DF, 5.10.1988. Disponível em: $<$ http://www.planalto.gov.br/ccivil_03/constituicao/constituicao.htm>. Acesso em: 18 ago 2014 .

BRASIL. Congresso Nacional. Lei $n^{\circ}$ 1.533, de 31 de dezembro de 1951. Altera disposições do Código do Processo Civil, relativas ao mandado de segurança. Diário Oficial da União, Brasília, DF, 31.12.1951. Disponível em: $<$ http://www.planalto.gov.br/ccivil_03/leis/11533.htm>. Acesso em: 18 ago 2014.

BRASIL. Congresso Nacional. Lei $n^{0}$ 5.869, de 11 de janeiro de 1973. Institui o Código de Processo Civil. Diário Oficial da União, Brasília, DF, 17.1.1973. Disponível em: <http://www.planalto.gov.br/ccivil_03/Leis/L5869.htm>. Acesso em: 18 ago 2014. BRASIL. Congresso Nacional. Lei $n^{0}$ 8.666, de 21 de junho de 1993. Regulamenta o art. 37, inciso XXI, da Constituição Federal, institui normas para licitações e contratos da Administração Pública e dá outras providências. Diário Oficial da União, Brasília, DF, 22.6.1993. Disponível em: < http://www.planalto.gov.br/ccivil_03/leis/18666cons.htm >. Acesso em: 18 ago 2014.

BRASIL. Congresso Nacional. Lei $\mathbf{n}^{0}$ 12.016, de 07 de agosto 2009. Disciplina o mandado de segurança individual e coletivo e dá outras providências. Diário Oficial da União, Brasília, DF, 10.8.2009. Disponível em: < 
Revista Eletrônica de Direito Processual - REDP. Volume 15. Janeiro a Junho de 2015

Periódico Semestral da Pós-Graduação Stricto Sensu em Direito Processual da UERJ. Patrono: José Carlos Barbosa Moreira. www.redp.com.br ISSN 1982-7636 PP 213-239 http://www.planalto.gov.br/ccivil_03/_ato2007-2010/2009/lei/112016.htm>. Acesso em: 18 ago 2014. 